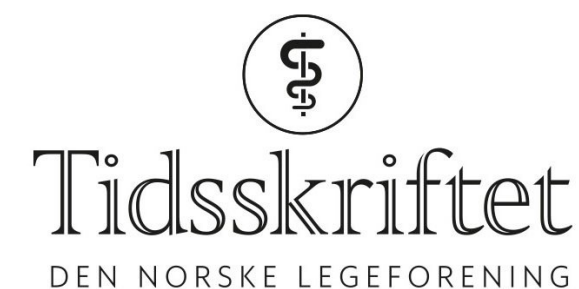

\title{
Ada Bugge
}

MINNEORD

KJELL MARTIN MOKSNES

Vår gode kollega Ada Bugge døde 4. juli 2018, 92 år gammel, etter en tids sykdom. Hun ble født i Troms $\emptyset$ 23. mars 1926, tok artium i Bærum i 1945 og ble cand.med. ved Universitetet i Oslo i 1952.

Etter turnustjenesten arbeidet hun et par år ved medisinsk og kirurgisk avdeling på Ullevål og Lovisenberg sykehus. Fra 1956 startet hun sin psykiatriske utdannelse og ble godkjent spesialist i psykiatri i 1963. Hun var overlege ved Gaustad sykehus og Østfold psykiatriske sykehus i Fredrikstad før hun kom til Dikemark sykehus i 1975. Hun var avdelingsoverlege en god periode og avsluttet sitt virke som seksjonsoverlege ved alderspsykiatrisk avdeling, Søndre Borgen i 1993.

Ada Bugge var skoleflink og bestemte seg tidlig for å bli lege. Hun gråt av glede da hun kom inn på medisinstudiet etter krigen som en av to kvinnelige studenter på kullet. Hun var en person som pasientene grep fatt i for å komme med sine spørsmål. Hun var en god lytter og en lege mange pasienter ble glad i og fikk tillit til. Hun interesserte seg særlig for de alvorligst syke. Hun hjalp mange unge med spiseforstyrrelser og hadde spesiell omsorg for personer med schizofreni. Hun så deres behov og viktigheten av kontinuitet $\mathrm{i}$ behandlingen over flere år, og la stor vekt på samtaleterapi. I 1986 var hun ett år på Åsgård sykehus for å dekke opp for legemangelen der. Hun lyttet til flere kvinnelige pasienter som fortalte om incest og hun trodde på dem. Helt til det siste ringte tidligere pasienter til henne og takket for den gode hjelp hun hadde gitt dem. På slutten var hun lei seg for nedbyggingen av psykiatrien. Ada Bugge var faglig solid, arbeidsom og samvittighetsfull. Hun var omsorgsfull og la sin sjel i arbeidet. Hun var en staselig dame, vennlig og tålmodig, og hun mente det hun sa.

Ada elsket å pakke sekk og telt og ta med barna til fjells, og hun likte å stelle i hagen. Som pensjonist tok hun mange turer til Italia. Hun elsket romaner, særlig norske klassikere, men også krim. Hun gjorde livet rikere for sine to barn, tre barnebarn og fikk oppleve at et oldebarn er på vei.

Det var trygt å være sammen med henne. Hun kunne tulle og det var mye latter og glede i samværene.

Våre tanker går spesielt til barna Dag og Anne og deres etterkommere som har mistet en god mor, bestemor og oldemor. 
(ㅇ) Tidsskrift for Den norske legeforening 2020. Lastet ned fra tidsskriftet.no 